\title{
The treatment of scaphoid non-unions with partial and total scaphoid in titanium custom-made 3D-printed prostheses and reconstruction of scapholunate interosseous ligament: a preliminary study
}

\author{
Alessio Cioffi, $\mathrm{MD}^{1}$, Mario Igor Rossello ${ }^{2}, \mathrm{MD}, \mathrm{PhD}$ \\ ${ }^{1}$ Department of Orthopaedic Surgery (DICHIRONS), University of Palermo, Palermo, Italy \\ ${ }^{2}$ Hand Surgery Department “Renzo Mantero”, Ospedale San Paolo, Savona, Italy
}

\section{Corresponding Author}

Alessio Cioffi, MD

Department of Orthopaedic Surgery (DICHIRONS)

University of Palermo

Via del Vespro, 90100, Palermo, Italy

Email: ale.cioffi90@gmail.com

\section{ABSTRACT}

The treatment of sequelae of scaphoid fractures is still one of the unsolved problems of hand surgery. Between January 2019 and July 2020 in the Hand Surgery Department of San Paolo's Hospital in Savona (Italy) 9 partial scaphoid in titanium custom-made 3D-printed prosthesis have performed in 9 patients (all men) with an average age of 27.5 years (minimum 18-maximum 37 years). The aim of the study is to evaluate over time the clinical-functional and radiographic results of the wrists treated with partial and total scaphoid titanium custom-made 3D-printed prostheses and reconstruction of SLIL. 


\section{INTRODUCTION}

The treatment of sequelae of scaphoid fractures is still one of the unsolved problems of hand surgery. These types of lesions, if diagnosed late, result in nonunions, with or without necrosis. The natural history is a radioscaphoid osteoarthritis, the alteration of the biomechanic complex of the radiocarpal joint, which ranges from the instability of intercalated segment (VISI or DISI) to carpal collapse (so called SNAC wrist) ${ }^{1}$. Many treatments are available to reconstruct the scaphoid or to prevent and treat the related sequelae: like bone grafts (free or pedunculated when the pseudoarthrosis is isolated, without carpal collapse phenomena), partial or total resection of the scaphoid in association with mediocarpal arthrodesis, corpectomy of the first row, total wrist replacement or total wrist arthrodesis. ${ }^{2-3-4}$ When is not possible to save the scaphoid and there are no mediocarpal or radiocarpal arthrosis signs or collapse, a total scaphoid prosthetic replacement can be considered for the treatment. While partial replacement is indicated when non-union has led to isolated aseptic necrosis of the proximal pole of the scaphoid. ${ }^{5}$

The history of scaphoid prostheses is long and studded with successes and failures. It started with the first scaphoid prosthesis made in vitallium in 1945, followed by the acrylic implant in 1950. ${ }^{6-7}$ Then Swanson's prosthesis of 1962 was constructed in Silistic, but it developed many problems of "silicon synovitis" which in some cases produced massive degeneration of the wrist, passing through the same in titanium which demonstrated good performances even at long term controls ${ }^{8}$, but never reached a wide diffusion. Later Bioprofile ${ }^{\circledR}$ introduced a pyrocarbon adaptive proximal scaphoid implant (APSI), based on a completely different concept of adaptation of the carpus to the implant, and not in an anatomical reconstruction ${ }^{9}$. The simplicity of the prosthesis allowed a good diffusion of the technique, with good results reported by many authors in the short and medium term, but with frequent phenomena of collapse of the carpus and penetration of the implant into the longterm neighboring bone segments. ${ }^{10}$ Since 2018, thanks to the development of powder technology and the custom made implants engineering, it is possible to build total or partial scaphoid prostheses created "made to measure" thanks to 3D CT reconstructions of the single wrist. The indications for this procedure are very compelling: scaphoid destruction, unsuitable for a reconstruction with grafting techniques, good wrist stability and absence of SNAC-wrist condition, as demonstrated by carpal height and radio-scaphoid angle measurements, absence of degenerative changes in the radial scaphoid facet and/or other carpal bones ${ }^{11}$. 
These new prostheses are built to allow the reconstruction of the scapholunate interosseous ligament (SLIL), an important element of stability of the implant and biomechanics of the carpus ${ }^{5}$. The aim of the study is to evaluate over time the clinical-functional and radiographic results of the wrists treated with partial and total scaphoid titanium custom-made 3D-printed prostheses and reconstruction of SLIL.

\section{MATERIALS AND METHODS}

\section{Partial scaphoid prosthesis}

Between January 2019 and July 2020 in the Hand Surgery Department of San Paolo's Hospital in Savona (Italy) 9 partial scaphoid in titanium custom-made 3D-printed prosthesis have performed in 9 patients (all men) with an average age of 27.5 years (minimum 18-maximum 37 years). There were involved 5 right wrists and 4 left wrists. All patients had a proximal pole of scaphoid non-union with necrosis and they failed the conservative or classical surgical treatment or result of diagnostic errors. The patients were submitted to preoperative MRI and TC, then the images were sent to $A D L E R^{\circledR}$ company to create custom-made 3D implants. None of these patients had SNAC wrist or radio-carpal arthritis (Figs. 1 e 2). The approach was the dorsal-radial, with a sinusoidal incision of about $5 \mathrm{~cm}$, medial to the course of the long extensor of the thumb, which was isolated and retracted, as well as the vascular structures and the sensory branches of the radial nerve. The radial extensors of the carpus have been mobilized and moved laterally to better highlight the radiocarpal dorsal ligament, which has been incised in inverted T-shape and dissected carefully by the carpus. All scaphoid bone was exposed and isolated. After removing the necrotic proximal pole and the remaining tissues of scapholunate ligament, the total distal pole was preserved. To reconstruct the scapholunate ligament, a palmaris longus tendon graft (PLTG) from the same wrist was used. Only in one case we had a problem to take palmaris longus tendon graft, so we chose to stabilize the implant with Garcia Elias's tenodesis with FRC tendon graft. Then the implant was prepared to be placed. First, a tape of PLTG was fixed through the corresponding notch of the implant. The implant was fitted into its space, and the remaining tape of PLTG was stabilized with 1 or 2 anchors on the lunate (Fig.3). After confirming a satisfactory bx

radiografically position (Fig.4), the stability of the implant was assessed by passively performing flexion and extension, laterality and rotation movements, before proceeding with the reconstruction of the radiocarpal dorsal ligament which was 
inserted on the radius with transosseous suture. Only in 3 cases we strengthened the ligament and the dorsal capsule with a flap of the extensor retinaculum. A suction drain was left in place for $24 \mathrm{~h}$ just to prevent hematoma formation. The day after surgery a thermoplastic splint was applied with the wrist in $10^{\circ}$ extension. Immobilization was sustained for 4 weeks and then X-rays were performed to confirm the satisfactory position of the implant. Subsequent rehabilitation was then conducted for 3 months. Clinical and X-rays checks are performed at 1, 3, 6 and 12 months after the surgical intervention to follow the restoration of range of motion and to detect any early displacement of the implant or any changes in the carpal bones (Fig.5).

\section{Total scaphoid prosthesis}

Between January 2019 and July 2020 in the Hand Surgery Department of San Paolo's Hospital in Savona (Italy) 10 total scaphoid titanium custom-made 3D-printed prosthesis have performed in 10 patients ( 8 male and 2 female) with average age of 33.3 years (minimum 26-maximum 41 years). There were involved 4 right wrists and 6 left wrists. All patients had scaphoid non-union, as result of diagnostic error or failure of surgical treatments and irreparable bone destruction. However, they had good wrist stability, no SNAC wrist condition (as demonstrated by carpal height and radio-lunate angle measurements) and absence of STT arthritis. Patients were submitted to preoperative $\mathrm{MRI}$ and $\mathrm{TC}$, then the images were sent to $\mathrm{ADLER}^{\circledR}$ company to create a correct size of custom-made 3D implant. The approach was the same for the partial scaphoid prosthesis. When the capsule was opened, all necrotic scaphoid was removed, except a small, volar portion of the distal pole, of about $3 \times 3$ $\mathrm{mm}$, must be left in place to preserve the radio-scapho-capitate ligament insertion. Then a hole was made in the trapezium under the control of the image amplifier. This hole was designed to host the distal tip of the prosthesis, a key point to stabilize the implant. To reconstruct the scapholunate ligament, Arthrex ${ }^{\mathrm{TM}}$ labral tape (Naples, FL, USA) was inserted into the lunate with an anchor. The implant was then prepared for the placement. First, the two cords of the labral tape were passed through the corresponding holes of the implant, and then the prosthetic distal tip was inserted into the trapezium hole ${ }^{5}$. The implant was fitted into its space, and the two labral tape cords were finally knotted in an apposite notch carved into the implant (Fig 6). The implant was therefore stabilized on both sides: distally by its tip inserted into the trapezium and proximally thanks to the labral wire fixed to the lunate. After confirming a radiographically satisfactory position, the implant stability was tested by moving the wrist in any direction. The closure of the capsule, the thermoplastic splint and postoperative checks were the same of partial prosthesis. 
Only in one case we had a distal dislocation of the stem at 1 month and we removed the implant and used 3-corner arthrodesis to stabilize the wrist.

\section{RESULTS}

\section{Partial scaphoid prosthesis}

We have been able to follow all the 9 patients with a mean follow-up of 18 months (minimum 12 months maximum 18 months). The evaluation criteria include carpal height ratio measured by Youm's method, radioscaphoid angle, extension and flexion wrist, radial deviation and ulnar deviation of the wrist, grip strength and pinch strenght by Jamar test on operated wrist and contralateral, pain VAS scale at rest and under load, DASH score and patient-rated wrist evaluation (PRWE). We have evaluated DASH score and PRWE pre-operative and 1 year post operation and the other outcomes on pre-operative, 1 month, 3 months, 6 months and 12 months post-operative. The X-rays were useful to show the correct position of prosthetic stem into trapezium body, any evidence of reabsorption or cysts in the carpal bones and any sign of biocompatibility. The clinical findings (Table 1) demonstrated that the carpal height ratio decreased of $9,5 \%$ from pre-operative to 1 year. The radioscaphoid angle decreased of $29 \%$ at 1 year. Flexion and extension wrist increased about $34 \%$ and $48 \%$ in 1 year from pre-operative. Radial deviation increased of $45 \%$ in 1 year, and ulnar deviation of $23 \%$. The grip strength improved from pre-operative to 1 year post-operative of 41,5\%, the pinch strength of $38 \%$. The VAS scale under load decreased of $77 \%$. DASH score decreased about $59 \%$ from pre-operative to 1 year, and PRWE about 48\%. All these rates are an average. We hadn't failure of the implant. We had only one failure in one case of the total prosthesis was dislocation at 1 month, and it was necessary to remove the implant and perform a 3-corner arthrodesis.

\section{Total scaphoid prosthesis}

We were able to follow 10 patients with a median follow-up of 18 months (minimum 12 months maximum 18 months). The evaluation criteria were the same for the partial implant. The clinical results (Table 2) demonstrated that the carpal height ratio decreased of $13 \%$ from pre-operative to 1 year. The radioscaphoid angle 
decreased of $16 \%$ at 1 year. Flexion and extension of the wrist increased about $46 \%$ and $40 \%$ in 1 year from pre-operative. Radial deviation increased of $65 \%$ in 1 year, and ulnar deviation of $16 \%$. The grip strength improved from pre-operative to 1 year post-operative of $47 \%$, the pinch strength of $41 \%$. The VAS scale under load decreased of $83 \%$. DASH score decreased of $58 \%$ from pre-operative to 1 year, and PRWE by $37 \%$. All these rates are just an average. Of the total prosthesis we had just one failure in one case which was a dislocation at 1 month, and it was necessary to remove the implant and perform a 3-corner arthrodesis.

\section{DISCUSSION}

The treatment of scaphoid non-unions is still controversial because there are many options to restore the wrist cinematic which is based on the characteristics of each patient. The replacement of scaphoid with partial or total titanium custom made 3D printed prosthesis is a valid choice for young patients with an unsuitable scaphoid for a reconstruction with grafting techniques and without degenerative or arthritis signs in the wrist. We had an improvement in all analyzed outcomes, in partial and total prosthesis (Table 1 and 2). The best result was for VAS pain scale, with a great improvement from pre-operative to 1 year post-operative, at rest and under load. (Table 1 and 2). DASH score and PRWE was acceptable with a hight grade of satisfaction for the patients. The reconstruction of SLIL in both procedures allowed a greater stability and prevents a midcarpal bones collapse in the medium term. In case of failure, the same more aggressive procedures to be considered as alternatives are always possible, such as scaphoidectomy and 4- or 3-corner arthrodesis or proximal row carpectomy. ${ }^{11}$

\section{CONCLUSIONS}

So far this study is the unique in Literature in this type of implants, even if preliminary. The use of these devices can mark new borders for the treatment of sequelae's scaphoid fractures and an expression of the new technologies made available by orthopedic prosthesis companies and the maximum concept of "Custom-made Prosthesis" on anatomy of single patient. Several studies shown substantial inter-individual differences in the shape of the carpal bones and motion patterns of the scaphoid. ${ }^{12-13-14}$ Considering this we believe that any scaphoid prosthesis and any biological scaphoid reconstruction must replicate the original shape of the bone as precisely as possible to minimize non-physiological kinematics and wear. This concept requires a patient-specific implant: So far 3D printing is the 
only way to realize such a device. A strong pro for scaphoid implant reconstruction concept is that it doesn't burn bridges, allowing in case of failure, the identical salvage procedures (PRC, 3 or 4 corner fusion) that could have been performed instead of. However, we believe that there are some critical issues for this study: the follow-up at only one year; the surgical approach must be dressed by expert hand surgery; the long time for manufacturing process of the prosthesis (about 3 weeks) and the elevate cost of the implants.

\section{BIBLIOGRAFY}

1. Watson HK, Ballet FL. The SLAC wrist: scapholunate advanced collapse pattern of degenerative arthritis. J Hand Surg 1984; 9A: 358-65.

2. Mathoulin C. Haerle M Vascularized bone graft from the carpal palmar artery for treatment of scaphoid non-union. J Hand Surg. 1998;23B:318-323

3. Kalicke $\mathrm{T}$, Burger $\mathrm{H}$, Muller EJ. A new vascularized cartilage-bone-graft for scaphoid nonunion with avascular necrosis of the proximal pole. Description of a new type of surgical procedure. Unfallchirurg 2008; 111: 201-5

4. Hastings $\mathrm{H}$, Boyer MI Total wrist arthrodesis, in Watson HK, Weinzweig J, The wrist, Lippincot Williams \& Wilkins 2001: 555-566

5. Mario Igor Rossello. A case of total scaphoid titanium custom-made 3Dprinted prostheses with one-year follow-up, Case Reports in Plastic Surgery and Hand Surgery, 2020, 7:1, 7-12

6. Legge RF. Vitallium prosthesis in the treatment of the carpal navicular fracture. West J Surg Obstet Gynecol. 1951;59(9):468-471.

7. Agner O. Treatment of non-united navicular fractures by total excision of the bone and the insertion of acrylic prostheses. Acta Orthop Scand. 1963;33(1-4): 235-245.

8. Swanson AB1, de Groot Swanson G, DeHeer DH, Pierce TD, Randall K, Smith JM, Van Gorp CC. Carpal bone titanium implant arthroplasty. 10 years' experience. Clin Orthop Relat Res. 1997 Sep;(342):46-58.

9. Daruwalla Z, Davies K, Shafighian A, Gillham NR. An alternative treatment option for scaphoid nonunion advanced collapse (SNAC) and radioscaphoid osteoarthritis: early results of a prospective study on the pyrocarbon 
adaptive proximal scaphoid implant (APSI). Ann Acad Med Singapore. 2013 Jun;42(6):278-84.

10. Poumellec MA, Camuzard O, Pequignot JP, Dreant N. Adaptive Proximal Scaphoid Implant: Indications and Long-Term Results. J Wrist Surg. 2019 Aug;8(4):344-350.

11.Spingardi O, Rossello MI. The total scaphoid titanium arthroplasty: A 15-year experience. Hand (N Y). 2011 Jun;6(2):179-84.

12. Nuttall D, Trail IA, Stanley JK.: Movement of the Scaphoid in the Normal Wrist. J Hand Surg Br 1998 Dec;23(6):762-4.

13. G I Bain, A Sood, N Ashwood, P C Turner, Q A Fogg: Effect of Scaphoid and Triquetrum Excision After Limited Stabilisation on Cadaver Wrist Movement. J Hand Surg Eur Vol 2009 Oct;34(5):614-7.

14.Philipp Honigmann, Ralf Schumacher, Romy Marek, Franz Bùttner, Florian Thieringer, and Mathias Haefeli: A three-dimensional printed patientspecific scaphoid replacement: a cadaveric study. Journal of Hand Surgery (European Volume) 0(0) 1-6 The Author(s) 2018 
medRxiv preprint doi: https://doi.org/10.1101/2021.09.05.21262363; this version posted September 6, 2021. The copyright holder for this preprint (which was not certified by peer review) is the author/funder, who has granted medRxiv a license to display the preprint in perpetuity. It is made available under a CC-BY-NC-ND 4.0 International license .

Fig. 1: Typical pre-operative Xray image of a case of proximal pole of scaphoid nonunion. No evidence of SNAC wrist or radio-carpal arthritis

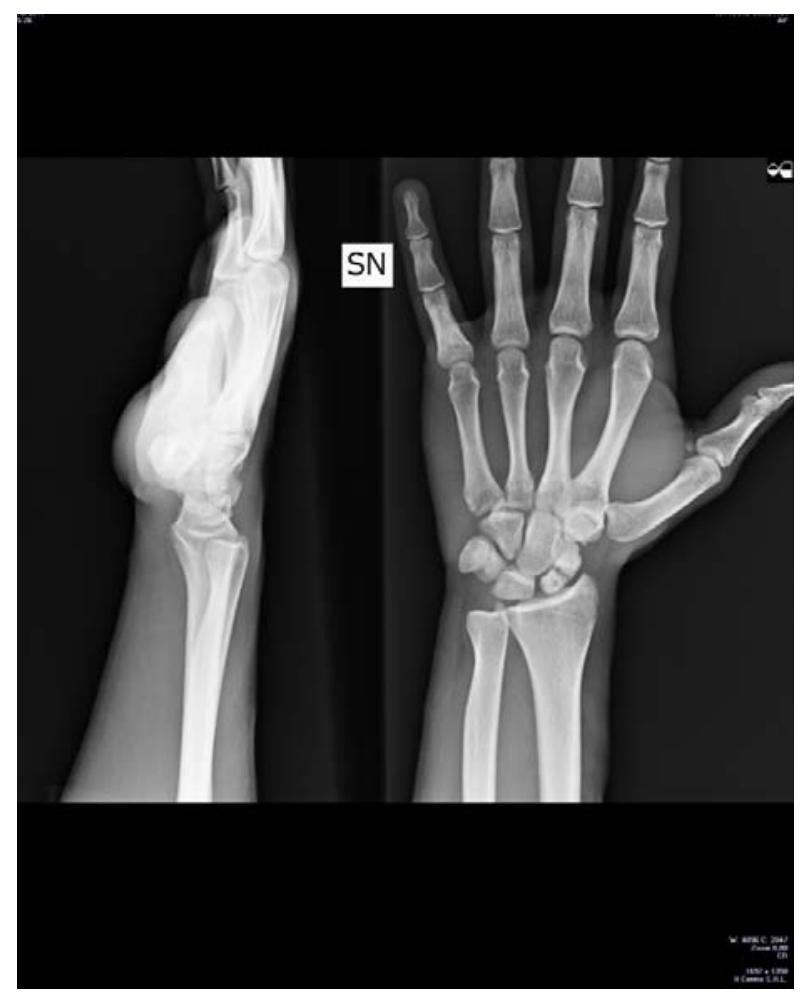


medRxiv preprint doi: https://doi.org/10.1101/2021.09.05.21262363; this version posted September 6, 2021. The copyright holder for this preprint

(which was not certified by peer review) is the author/funder, who has granted medRxiv a license to display the preprint in perpetuity.

It is made available under a CC-BY-NC-ND 4.0 International license.

Fig. 2: Typical pre-operative MRI image of a case of proximal pole of scaphoid nonunion with necrosis area.

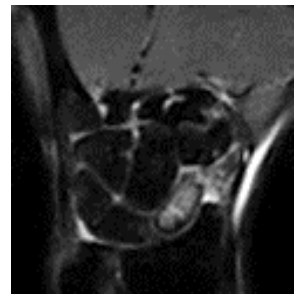


medRxiv preprint doi: https://doi.org/10.1101/2021.09.05.21262363; this version posted September 6, 2021. The copyright holder for this preprint (which was not certified by peer review) is the author/funder, who has granted medRxiv a license to display the preprint in perpetuity. It is made available under a CC-BY-NC-ND 4.0 International license .

Fig. 3: Intraoperative view. The titanium custom-made 3D-printed prosthesis is put in place; a PLTG passing through the prosthetic body will be fixed to the lunate.

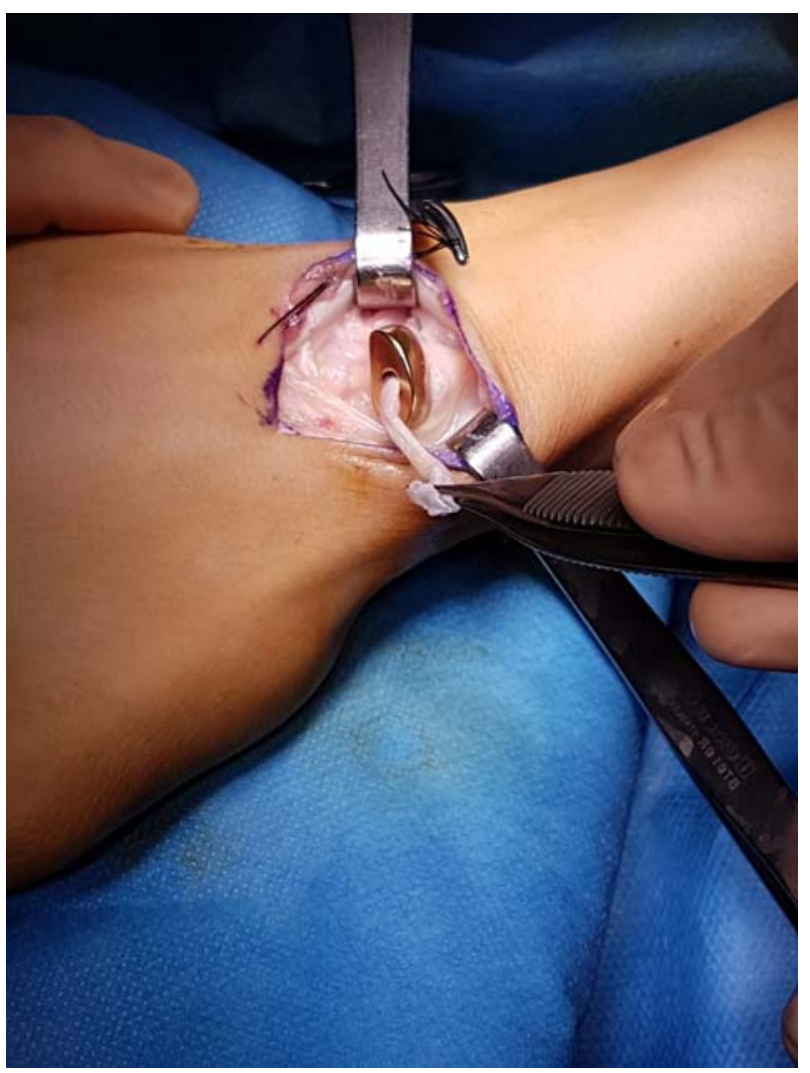


medRxiv preprint doi: https://doi.org/10.1101/2021.09.05.21262363; this version posted September 6, 2021. The copyright holder for this preprint (which was not certified by peer review) is the author/funder, who has granted medRxiv a license to display the preprint in perpetuity. It is made available under a CC-BY-NC-ND 4.0 International license .

Fig. 4: The perioperative radiography, the good prosthesis position was verified.
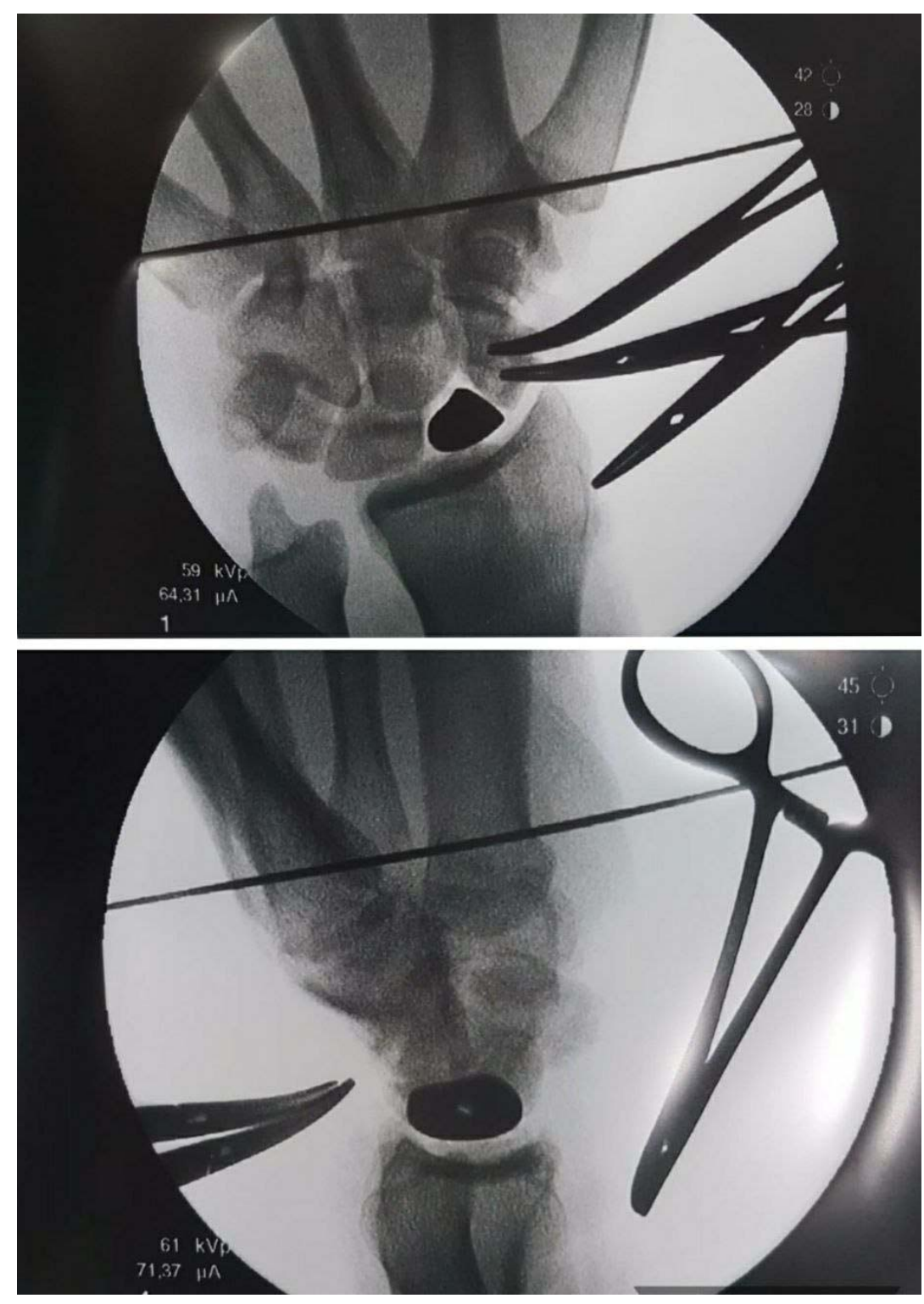
medRxiv preprint doi: https://doi.org/10.1101/2021.09.05.21262363; this version posted September 6, 2021. The copyright holder for this preprint (which was not certified by peer review) is the author/funder, who has granted medRxiv a license to display the preprint in perpetuity. It is made available under a CC-BY-NC-ND 4.0 International license .

Fig. 5: At 1-year follow up, radiography showed a correct radioscaphoid angle, no displacement or sign of carpal arthritis or other problems.

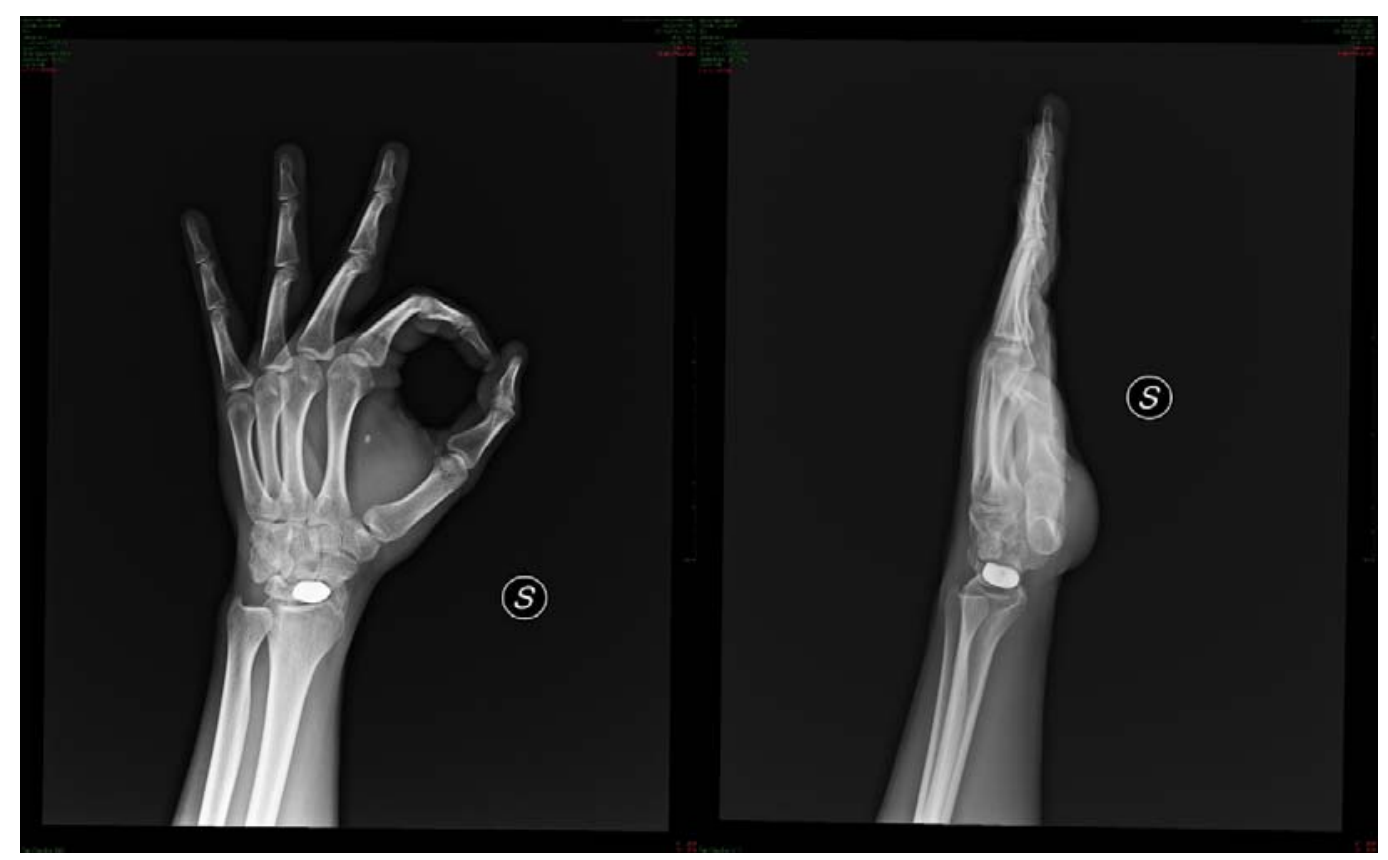


medRxiv preprint doi: https://doi.org/10.1101/2021.09.05.21262363; this version posted September 6, 2021. The copyright holder for this preprint (which was not certified by peer review) is the author/funder, who has granted medRxiv a license to display the preprint in perpetuity. It is made available under a CC-BY-NC-ND 4.0 International license .

Fig. 6: The titanium implant was positioned. ArthrexTM labral tape was fixed into the lunate and passed through the implant. The distal stem of the implant was set into the hole prepared into the trapezium.

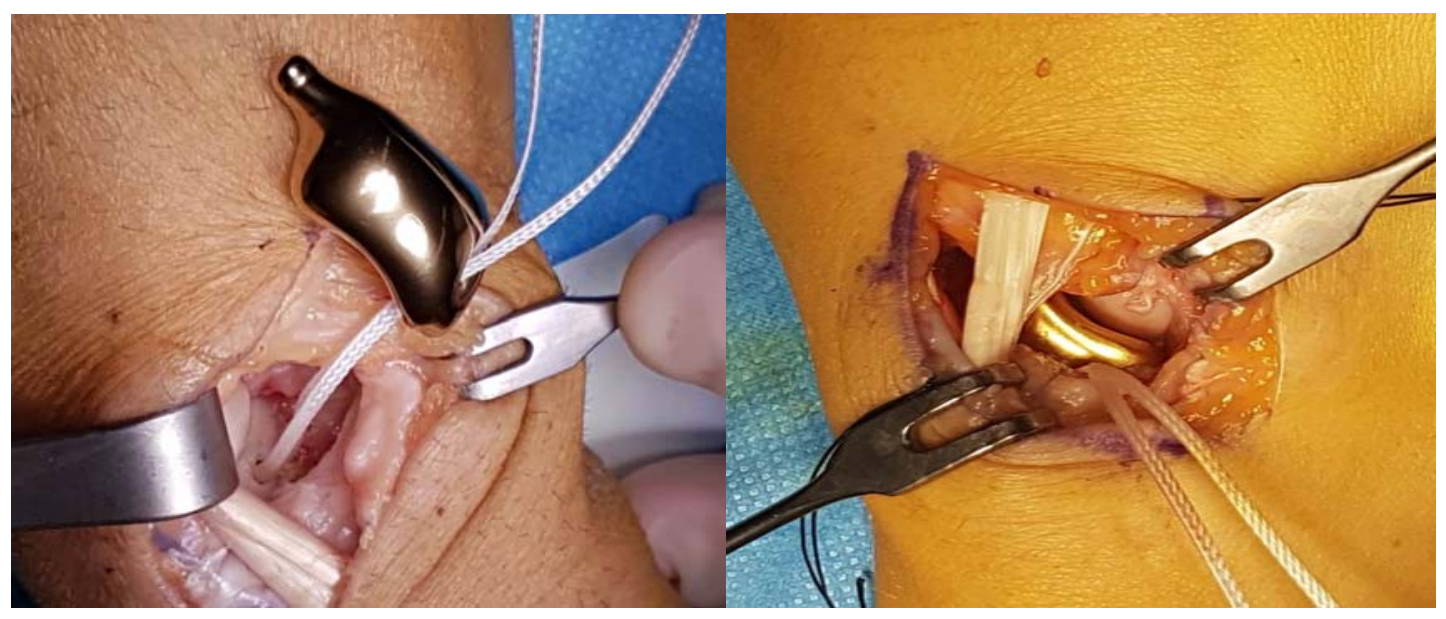


medRxiv preprint doi: https://doi.org/10.1101/2021.09.05.21262363; this version posted September 6, 2021. The copyright holder for this preprint (which was not certified by peer review) is the author/funder, who has granted medRxiv a license to display the preprint in perpetuity.

It is made available under a CC-BY-NC-ND 4.0 International license .

Table 1: Rx and Clinical outcomes of partial prosthesis

\begin{tabular}{|c|c|c|c|c|c|}
\hline & $\begin{array}{l}\text { PRE- } \\
\text { OPERATIVE }\end{array}$ & 1 MONTH & 3 MONTHS & 6 MONTHS & 12 MONTHS \\
\hline CARPAL HEIGHT & $0,84(1,98-0,52)$ & $0,77(1,96-0,45)$ & $0,77(1,96-0,44)$ & $0,76(1,95-0,44)$ & $0,76(1,94-0,44)$ \\
\hline $\begin{array}{l}\text { RADIOSCAPHOID } \\
\text { ANGLE }\end{array}$ & $45,75^{\circ}(66-37)$ & $30,62^{\circ}(43-20)$ & $32,5^{\circ}(42-30)$ & $33,87^{\circ}(43-30)$ & $32,37^{\circ}(43-30)$ \\
\hline EXTENSION & $33,57^{\circ}(70-0)$ & $53,57^{\circ}(65-30)$ & $57,14^{\circ}(70-35)$ & $63,57^{\circ}(80-50)$ & $64,28^{\circ}(80-50)$ \\
\hline FLEXION & $40^{\circ}(70-20)$ & $41,42^{\circ}(50-35)$ & $47,85^{\circ}(60-40)$ & $59,28^{\circ}(70-45)$ & $60,71^{\circ}(70-45)$ \\
\hline $\begin{array}{l}\text { RADIAL } \\
\text { DEVIATION }\end{array}$ & $12,85^{\circ}(35-5)$ & $17^{\circ}(22-5)$ & $21,42^{\circ}(30-15)$ & $26,42^{\circ}(60-15)$ & $26,45^{\circ}(60-15)$ \\
\hline $\begin{array}{l}\text { ULNAR } \\
\text { DEVIATION }\end{array}$ & $27,85^{\circ}(45-10)$ & $36,14^{\circ}(50-30)$ & $39,28^{\circ}(45-35)$ & $37,14^{\circ}(50-20)$ & $36,42^{\circ}(50-20)$ \\
\hline \multicolumn{6}{|l|}{$\begin{array}{l}\text { GRIP (JAMAR } \\
\text { TEST) }\end{array}$} \\
\hline \multirow{2}{*}{$\begin{array}{l}\text { OPERATED W. } \\
\text { CONTROLATERAL }\end{array}$} & $17 \mathrm{kgm}(22-10)$ & $12 \mathrm{kgm}(15-10)$ & $15,6 \mathrm{kgm}(24-10)$ & $24,7 \mathrm{kgm}(31-20)$ & $29,1 \mathrm{kgm}(38-24)$ \\
\hline & 39 kgm (50-26) & $37 \mathrm{kgm}(46-25)$ & $37,1 \mathrm{kgmn}(48-26)$ & $36,4 \mathrm{kgm}(48-26)$ & $30.8 \mathrm{kgm}(50-28)$ \\
\hline \multicolumn{6}{|l|}{ PINCH } \\
\hline OPERATED W. & $5,1 \mathrm{kgm}(6,5-4)$ & $6,2 \mathrm{kgm}(8,5-3,5)$ & $6,6 \mathrm{kgm}(8,5-3,5)$ & $7,5 \mathrm{kgm}(8,9-6)$ & 8 kgm (9-7) \\
\hline CONTROLATERAL & $\begin{array}{l}8,6 \mathrm{kgm}(10- \\
6,5)\end{array}$ & $8 \mathrm{kgm}(9,5-6)$ & $8,6 \mathrm{kgm}(9,5-6,5)$ & $8,5 \mathrm{kgm}(9,5-6,5)$ & $\begin{array}{l}8,6 \text { kgm }(9,5- \\
6,5)\end{array}$ \\
\hline \multicolumn{6}{|l|}{ PAIN VAS SCALE } \\
\hline AT REST & $3,6(10-1)$ & $1,9(5-0)$ & $0,4(1-0)$ & 0 & 0 \\
\hline UNDER LOAD & $7,4(10-5)$ & $4,4(8-2)$ & $3,1(5-2)$ & $2,5(4-2)$ & $1,7(3-1)$ \\
\hline \multirow[t]{2}{*}{ DASH SCORE } & \multicolumn{3}{|c|}{ PRE-OPERATIVE } & \multicolumn{2}{|l|}{1 YEAR } \\
\hline & \multicolumn{3}{|c|}{$22,4(51-12,9)$} & \multicolumn{2}{|c|}{$9,2(30,8-0,8)$} \\
\hline \multirow[t]{2}{*}{ PRWE } & \multicolumn{3}{|c|}{ PRE-OPERATIVE } & \multicolumn{2}{|l|}{1 YEAR } \\
\hline & \multicolumn{3}{|c|}{$33,7(88-28)$} & \multicolumn{2}{|l|}{$17,5(62-2)$} \\
\hline
\end{tabular}


Table 2: Rx and Clinical outcomes of total prosthesis

\begin{tabular}{|c|c|c|c|c|c|}
\hline & $\begin{array}{l}\text { PRE- } \\
\text { OPERATIVE }\end{array}$ & 1 MONTH & 3 MONTHS & 6 MONTHS & 12 MONTHS \\
\hline CARPAL HEIGHT & $0,61(0,85-0,50)$ & $0,59(0,80-0,45)$ & $0,58(0,80-0,45)$ & $0,53(0,80-0,45)$ & $0,53(0,80-0,45)$ \\
\hline $\begin{array}{l}\text { RADIOSCAPHOID } \\
\text { ANGLE }\end{array}$ & $40,9^{\circ}(60,2-12)$ & $34,6^{\circ}(58-44,5)$ & $35^{\circ}(58-32)$ & $36,8^{\circ}(58-30)$ & $34,2^{\circ}(58-30)$ \\
\hline EXTENSION & $31,4^{\circ}(55-20)$ & $42^{\circ}(65-25)$ & $47,8^{\circ}(70-30)$ & $47,1^{\circ}(70-35)$ & $52,1^{\circ}(75-45)$ \\
\hline FLEXION & $25,7^{\circ}(45-10)$ & $36,7^{\circ}(50-12)$ & $44,2^{\circ}(60-20)$ & $44,2^{\circ}(60-25)$ & $47,8^{\circ}(60-35)$ \\
\hline $\begin{array}{l}\text { RADIAL } \\
\text { DEVIATION }\end{array}$ & $10^{\circ}(25-0)$ & $13,5^{\circ}(25-3)$ & $16,8^{\circ}(25-8)$ & $20^{\circ}(30-10)$ & $28,5^{\circ}(45-20)$ \\
\hline $\begin{array}{l}\text { ULNAR } \\
\text { DEVIATION }\end{array}$ & $29,7^{\circ}(60-10)$ & $29^{\circ}(35-20)$ & $29,7^{\circ}(35-25)$ & $32,1^{\circ}(45-30)$ & $35,5^{\circ}(45-30)$ \\
\hline \multicolumn{6}{|l|}{$\begin{array}{l}\text { GRIP (JAMAR } \\
\text { TEST) }\end{array}$} \\
\hline OPERATED W. & $13,6 \mathrm{kgm}(20-4)$ & 15 kgm (22-5) & $18,8 \mathrm{kgm}(26-12)$ & $22,4 \mathrm{kgm}(30-13)$ & $25,7 \mathrm{kgm}(32-18)$ \\
\hline CONTROLATERAL & $29 \mathrm{kgm}(46-25)$ & $28,7 \mathrm{kgm}(46-24)$ & 34,7 kgm (46-24) & $37,5 \mathrm{kgm}(52-24)$ & $36,5 \mathrm{kgm}(48-24)$ \\
\hline \multicolumn{6}{|l|}{ PINCH } \\
\hline OPERATED W. & $5 \mathrm{kgm}(10-1,8)$ & $4,7 \mathrm{kgm}(12-2)$ & $10,5 \mathrm{kgm}(16-2,5)$ & $8 \mathrm{kgm}(16-5)$ & $8,6 \mathrm{kgm}(16-10)$ \\
\hline CONTROLATERAL & $11,2 \mathrm{kgm}(22-7)$ & $11,2 \mathrm{kgm}(22-6)$ & $10,5 \mathrm{kgm}(22-6)$ & $10,7 \mathrm{kgm}(22-6)$ & $10,7 \mathrm{kgm}(22-6)$ \\
\hline \multicolumn{6}{|l|}{ PAIN VAS SCALE } \\
\hline AT REST & $5,5(8-2)$ & $1,8(3-1)$ & $1(2-0)$ & $0,8(2-0)$ & $0,1(1-0)$ \\
\hline UNDER LOAD & $8,2(10-6)$ & $4,7(8-2)$ & $3(6-2)$ & $3(5-0)$ & $1,4(5-0)$ \\
\hline \multirow[t]{2}{*}{ DASH SCORE } & \multicolumn{3}{|c|}{ PRE-OPERATIVE } & \multicolumn{2}{|l|}{1 YEAR } \\
\hline & \multicolumn{3}{|c|}{$28,2(67,5-11,8)$} & \multicolumn{2}{|c|}{$11,8(28,3-1,7)$} \\
\hline \multirow[t]{2}{*}{ PRWE } & \multicolumn{3}{|c|}{ PRE-OPERATIVE } & \multicolumn{2}{|l|}{1 YEAR } \\
\hline & \multicolumn{3}{|c|}{$35,6(82-15)$} & \multicolumn{2}{|c|}{$22,5(51-7)$} \\
\hline
\end{tabular}


medRxiv preprint doi: https://doi.org/10.1101/2021.09.05.21262363; this version posted September 6, 2021. The copyright holder for this preprint (which was not certified by peer review) is the author/funder, who has granted medRxiv a license to display the preprint in perpetuity.

\section{It is made available under a CC-BY-NC-ND 4.0 International license .}

Fig. 7: The range of motion after 1 year

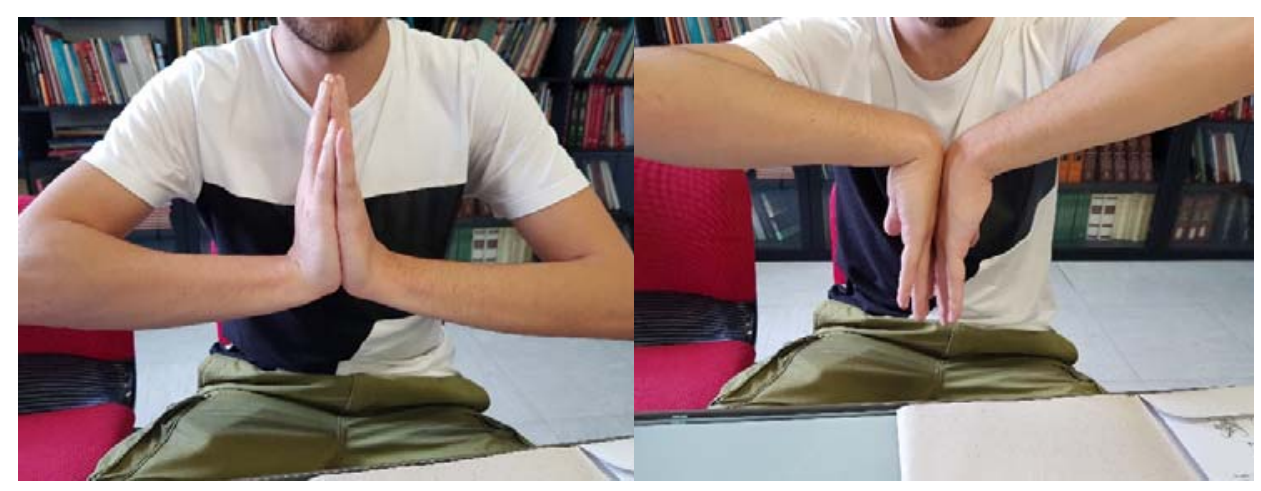

